\title{
Az élelmiszer-fogyasztói szokások változása a COVID-19 vírus megielenéséhez kapcsolódóan Magyarországon
}

\author{
Soós Gabriella \\ Eöłvös Loránd Tudományegyetem \\ Eszterházy Károly Egyetem
}

\section{A TANULMÁNY CÉLJA}

A COVID-19 pandémia kitörése és drasztikus terjedése gazdasági sokkhatást okozott, amely mérhetô változásokat hozott a fogyasztói magatartásban is. A kutatás célja, hogy felmérje, hogy a pandémia milyen hatást gyakorolt a fogyasztói magatartásra, hogyan változtatta meg az élelmiszervásárlással kapcsolatos döntési tényezőket.

\begin{abstract}
ALKALMAZOTT MÓDSZERTAN
2020 március-áprilisában online kérdőíves felmérést végeztünk elsősorban közösségi média, levelezőlisták felhasználásával. A kapott minta 928 fös, nem reprezentatív. A kérdőív első szegmensében az élelmiszerválasztási döntéseket mértük fel. A második rész a járvány által bekövetkezett változásokra fókuszált, míg a harmadik részben a háttérváltozókat helyeztük el. A leíró statisztikai elemzésen túl kapcsolatvizsgálatot végeztünk elsősorban nem, életkor, foglalkozás, családnagyság, jövedelem alapján és kerestük a jellemző magatartási mintázatokat. Ezt követően javaslatokat fogalmaztunk meg a lehetséges marketing és kereskedelmi eszközökre vonatkozóan.
\end{abstract}

\section{LEGFONTOSABB EREDMÉNYEK}

Kutatásunkban vizsgáltuk a fogyasztók élelmiszervásárlási magatartásában bekövetkező változásokat a veszélyhelyzet elrendelését követő 2-3 hétben. Mérhetően eltolódtak az arányok a beszerzés helyét illetỏen. A nagyobb bevásárlóközpontok helyett kisebb boltokat, piacokat választanak a fogyasztók nagyobb arányban. Csökkent a vásárlás gyakorisága, ugyanakkor nő az igény a pénzhelyettesítő fizetési eszközök alkalmazására. Még elsősorban a bankkártyás, hitelkártyás fizetés a leginkább elvárt, ugyanakkor az elöre fizetés (átutalás), mobilfizetés és virtuális számlák iránti igény is megjelenik. Megnőtt az internetes beszerzési források szerepe, ami új eszközöket ad a kereskedők kezébe, például az egészséges életmóddal kapcsolatos tájékoztatást illetően.

\section{JAVASLATOK}

Mivel a korábbi tapasztalatok fontos tényezöt jelentenek az élelmiszerek közötti döntés során, így a márkaépítés lényeges, illetve a marketingkommunikációnak a fogyasztók kockázatcsökkentését, a bizalom megteremtését kell szolgálnia.

A helyi termékek és termelők felértékelődése lehet hosszú távú is, így a kistermelőknek ezeket a lehetöségeket célzott kommunikációval, jó minőségủ termékekkel és szolgáltatásokkal érdemes megalapozni.

A fogyasztók kockázatcsökkentésének fontos eszköze az élelmiszerbiztonság és az ezzel kapcsolatos tájékoztatás, amelyben az érintett hatóságok is szerephez juthatnak, illetve a hiteles tájékoztatással, garanciákkal segíthetik a döntést.

Kulcsszavak: fogyasztói magatartás, attitüd, élelmiszer-fogyasztás, marketing, COVID-19

DOI: 10.15170/MM.2020.54.03.02 


\section{BEVEZETŐ INTRODUCTION}

A világot régóta nem látott sokkhatásként érte a 2019-ben induló COVID-19 járvány. Bár eleinte sokan nem hitték, hogy ez egy kiterjedt, világszintủ probléma lesz, már sokan dolgoznak azon, hogy megbecsüljék a gazdasági és egyéb hatásokat. Az azonban már most jól látszik, hogy az új helyzet, az elszeparálódás, a cseppfertőzéstől való félelem megváltoztatja a vásárlási szokásokat, ez pedig alapvetően befolyásolja a fogyasztói döntés folyamatát. Jelen kutatás célja megvizsgálni, hogy az élelmiszerfogyasztói attitűd alapvető tényezői hogyan változtak a járvány hatására a korlátozások bevezetését követően. Fontos megjegyezni, hogy a hosszú távú trendek vizsgálata jelen kezdeti időszakban még nem lehetséges, így csak a rövid távú hatásokra helyezzük a hangsúlyt. A kutatás a pandémia kezdeti szakaszában, az első sokkhatás után kezdődött és fejeződött be, ezért jelen helyzetre vonatkozóan hasonló kutatások még nem vagy alig állnak rendelkezésre, más járványokkal pedig a jelenlegi közvetlenül nem összehasonlítható.

A kutatás legföbb kérdései: Hogyan változott az élelmiszerbeszerzés gyakorisága és forrása a pandémia hatására? Hogyan változtak az élelmiszervásárlás során alkalmazott fizetési módok? Milyen fogyasztói attitűd-változást okozott a járvány? Milyen kapcsolat van a nem, az életkor, a foglalkozás jellege, a lakóhely, a családi állapot és végzettség, valamint az élelmiszerbeszerzési jellemzők és azok változása között?

\section{Afogyasztói kockázat The risk of consumer}

A fogyasztó egy szokványos vásárlási szituációban is számos kockázattal szembesül. Amellett, hogy a hasznosságát igyekszik maximalizálni egy-egy döntése során, a kockázatok mértékét is csökkenteni akarja.

A XX. század elején Knight (1921) különbséget tett bizonytalanság és kockázat között. A kockázat abból származik, hogy korábbi tapasztalatok alapján bizonyos körülménycsoportok kimenetele ismert, így a priori kalkulációval vagy a múlt statisztikai becslésével értelmezhető. A bizonytalanság abból származik, hogy nem ismerjük a befolyásoló körülményeket, mert azok jelentős mértékben egyediek (Knight 1921, 118). Így a kockázat kvantitatívan mérhető, míg a bizonytalanság legfeljebb kvalitatívan elemezhető.
Bauer $(1960,14)$ szerint a fogyasztói magatartásban akkor merül fel kockázat, ha a fogyasztó valamely tevékenysége következményekkel jár, amelyek bekövetkezésének hozzávetőleges valószínűségét nem tudja előrejelezni és amelyek közül legalább egy nem kedvező.

A jelenlegi fogyasztói bizonytalanság tehát abból fakad, hogy a sokkhatásként érkezö helyzet gyakorlatilag ismeretlen és kiszámíthatatlan feltételek között kényszeríti öket döntésre. Ráadásul a közösségi médiában terjedő téves információk, álhírek egy újfajta, információs járványt, infodémiát indítottak el, ami félelmet, zavarodottságot kelt és sebezhetővé teszi az érintetteket (Kulkarni et al. 2020).

A folyamatot jelentősen befolyásolja a fogyasztók kockázattürő képessége is. Ez nem csupán az anyagi helyzetből, a munkahely jellegéből vagy a társadalmi státuszból fakad, hanem a fogyasztók attitüdje is meghatározó e téren. Ráadásul a kockázatcsökkentésre alkalmazott különbözö módszerek (elkerülés, csökkentés, megosztás, viselés) költségei a döntés függvényében növekedhetnek (Vasvári 2015), ez a jelenlegi helyzetben jól érzékelhető. Multiplikáló jelleggel a költségnövekedés is kockázati tényezöként merül fel.

Vélhetően a jelen trenddel ellentétes, ún. fogyasztói ellenállás-minták is megjelennek, melyek az eddig formákhoz, pl. etikus fogyasztás, fair trade, önkéntes egyszerüsítés (Culiberg \& Bajde 2013, Szakály és tsai 2017) hasonlóak, ugyanakkor a kiváltó ok valószínüleg egy új irányt fog indítani.

Vizsgálatunkban a kockázat független tényezöként értelmezendő, amely kiváltó oka a fogyasztói magatartás megváltozásának (Fürediné 2008).

\section{A pandémia és a fogyasztói magatartás The pandemia and consumer behavior}

A legtöbbek által még sosem látott pandémia és az ezzel kapcsolatos korlátozások az élet számos területén, így a fogyasztásban is változásokat hoztak. Az Ipsos a kijárási korlátozások bevezetésétől kezdve tracking kutatással vizsgálja a magatartás változásait. A pandémia hatására a felnőtt hazai lakosság fele $(52 \%)$ egyáltalán nem hagyja el otthonát, míg tizenkettőből csupán egy fö jár el otthonából továbbra is változatlanul (8\%). A válaszadók 31\%-a otthonról dolgozik, közülük $51 \%$ felsőfokú végzettségü. A home office alkalmazásának lehetősége a középső régióban és a felsőfokú végzettségủek között nagyobb arányú. 21\%-uk munkarendje változik. A megkérdezettek 26\%-a költ 
többet, mint a járvány előtt. A felmérés jól mutatja, hogy a bevásárlóközpontokba járás csökken, míg a házhoz rendelés aránya nő (Ipsos 2020).

A KSH 2020. március 4-én közzétett gyorsjelentése alapján az év első két hónapjában, amikor a járványról már érkeztek hírek, de az első magyar fertőzésekről érkező hírek (március 4.) és a WHO világjárvánnyá nyilvánítás (március 11.) csak később érkezett meg, már érzékelhető volt a tartalékoló vásárlás a külföldi híreknek betudha- tóan. Januárban 7,6\%-kal nőtt a kiskereskedelmi forgalom az előző év azonos időszakához képest, ebből az élelmiszer-jellegü vegyeskereskedelem 4,9\%-kal bővült. A csomagküldő kereskedelem forgalmának növekedése $30 \%$-os volt ebben a hónapban (KSH 2020).

Látható, hogy a fogyasztók az elkövetkező időszakot bizonytalannak ítélték meg, így a tartós élelmiszerek felhalmozásával igyekeztek csökkenteni a kockázatot. Ehhez jelentős tökét is feláldoztak.

1. táblázat: A minta megoszlása (n=928)

Table 1. The distribution of sample $(n=928)$

\begin{tabular}{|c|c|c|c|}
\hline Nem & Megoszlás, \% & Munkavállalás & Megoszlás, \% \\
\hline Férfi & 17,8 & Teljes munkaidőben dolgozik & 69,8 \\
\hline Nö & 82,2 & Részmunkaidőben dolgozik & 7,5 \\
\hline Életkor & Megoszlás, \% & Nyugdíjas & 5,1 \\
\hline 18 év alatt & 0,2 & Munkanélküli & 2,8 \\
\hline $18-25$ éves & 12,6 & Háztartásbeli & 7,4 \\
\hline 26-35 éves & 25,1 & Tanuló & 7,4 \\
\hline 36-45 éves & 29,2 & Munka jellege & Megoszlás, \% \\
\hline 46-55 éves & 21,0 & Nehéz fizikai munkát végez & 2,9 \\
\hline 56-65 éves & 9,7 & Könnyebb fizikai munkát végez & 8,0 \\
\hline 65 év felett & 2,2 & Szellemi munkát végez, ami mozgással jár & 19,4 \\
\hline Lakóhelye & Megoszlás, \% & Szellemi ülő munkát végez & 50,4 \\
\hline föváros & 14,1 & Nem dolgozik & 19,3 \\
\hline megyeszékhely & 33,1 & Családi állapot & Megoszlás, \% \\
\hline város & 26,2 & Házas/élettársi kapcsolatban él & 72,8 \\
\hline község & 25,9 & Elvált/özvegy & 9,4 \\
\hline egyéb & 0,3 & Hajadon/nőtlen & 17,8 \\
\hline külföld & 0,4 & Végzettség & Megoszlás, \% \\
\hline $\begin{array}{l}\text { Háztartás } \\
\text { létszáma }\end{array}$ & Megoszlás, \% & Alapfokú & 2,0 \\
\hline 1 fö & 13,7 & Középfok érettségi nélkül & 4,9 \\
\hline 2 fó & 24,9 & Középfok érettségivel & 28,2 \\
\hline 3 fö & 26,8 & Felsőfok diploma nélkül & 12,2 \\
\hline 4 fó & 22,5 & Felsőfok diplomával & 48,8 \\
\hline 5 fö & 9,7 & Tudományos fokozat & 3,9 \\
\hline 6 fö vagy több & 2,4 & & \\
\hline
\end{tabular}

Forrás: saját számitás 


\section{ANYAG ÉS MÓDSZER MATERIAL AND METHOD}

A felmérést 2020. március 24. és április 3. között végeztük, tehát a magyarországi veszélyhelyzet elrendelését követő 2-3. hétben. A kérdőív 30 kérdést tartalmazott. Az első részben a vásárlási szokásokról kérdeztünk a járványt megelőzően, majd a veszélyhelyzet bejelentését követő változásokra tértünk át. A kérdőív végén háttérváltozókat és az érintettséget vizsgáló kérdéseket helyeztünk el. Az attitüdvizsgálatra elsősorban feleletválasztós és Likert-skálás kérdéseket alkalmaztunk.

A kérdőívet online juttattuk el a megkérdezettekhez, privát útvonalakat és a közösségi médiát kihasználva. Rövid idő alatt 928 válasz érkezett, melyek kivétel nélkül érvényesek voltak, így az elemzésbe az összes válaszív bevonható volt. Az alkalmazott módszer korlátai miatt a reprezentativitást nem tudtuk biztosítani, de a nagy elemszám miatt jól hasznosítható eredmények születtek. Az adatfeldolgozás SPSS 23 és Excel szoftverek segítségével történt.

Az elemzés során elsősorban leíró statisztikai és kapcsolatvizsgálati módszereket alkalmaztunk. Az asszociációs kapcsolatnál a Cramer-mutatót tekintettük mérvadónak, melynek elvárt minimális szintje 0,15 volt. Csak azon kapcsolatokat elemeztük, amelyeknél az összefüggés elvárt szignifikancia szintje $5 \%$.
A járvány előtt és utáni magatartás tekintetében páros t-próbával vizsgáltuk, hogy mely tényezők esetén volt tapasztalható szignifikáns különbség. Emellett variancia-analízist használtunk a magatartási tényezök és a háttérváltozók kapcsolatának megállapításához, illetve ha a mintaszórások azonossága nem állt fenn, akkor Welch-próbát. A szóráshomogenitást Levene-teszt segítségével vizsgáltuk. A minta összetételét az 1. táblázat mutatja be.

\section{EREDMÉNYEK RESULTS}

A kérdőív első felében a járványt megelőző magatartás jellemzőit térképeztük fel, majd ehhez összehasonlító adatokat igyekeztünk feltárni a járvány kitörését követő időszakból.

\section{A vásárlás helye Place of purchase}

A jellemző, élelmiszervásárlásoknál alkalmazott bolttípusok megoszlása már a kezdetektől jól láthatóan változott. A bolttípus választásának változását páros t-próba segítségével vizsgálva a változás szignifikáns $(\mathrm{t}=8,9, \alpha=0,000)$. A hipermarketben történő beszerzések részaránya 32,5\%-ról 20,7\%-ra esett vissza. Hasonló, de kisebb mértékủ változás tapasztalható a szupermarketeknél is: 51,8\%-ról 45,9\%-ra esett vissza a típus választása. A kisméretü, lokális élelmiszer szaküzletek választása növekedett (elöbbi 5,0-ról 15,6\%-ra, utóbbi 5,6-ról 10,7\%-ra) (1. ábra). 


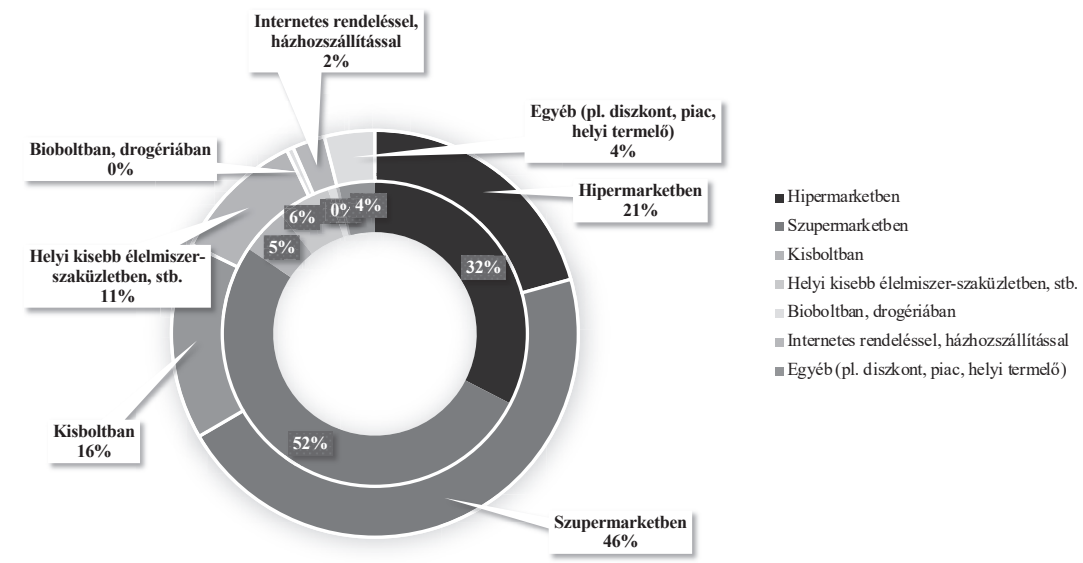

Forrás: saját szerkesztés

A McKinsey 42 országra kiterjedő vizsgálatot végzett a fogyasztói magatartás változására, az optimista vs. pesszimista kilátásokra vonatkozóan. Eszerint a nagyobb bevásárlóközpontokban való vásárlás egyértelmüen visszaszorul a járvány után a korábbiakhoz képest (McKinsey 2020).

Az idősebb korosztály, a nyugdíjasok a többi szegmenshez képest nagyobb arányban vásárolnak helyi kisebb élelmiszerszaküzletben, míg a munkanélküliek a pékségben, zöldségesben. A teljes- vagy részfoglalkozásúak nagyobb arányban a szupermarketeket, majd a hipermarketeket keresik fel, míg a háztartásbeli csoportnál ez az arány éppen fordított, náluk elsődleges a hipermarketekben történő élelmiszerbeszerzés. A foglalkozás jellege és a munkavégzés típusa (szellemi, fizikai) között nem találtunk szignifikáns összefüggést.

A lakóhely szignifikáns kapcsolatot mutat a beszerzés helyével. A fővárosiak legjellemzőbben szupermarketekben vásárolnak (71,0\%). A megyeszékhelyen, városokban lakókra a szuper- és hipermarketek ilyen sorrendủ kombinációja jellemző. A községekben lakóknál a legmagasabb a helyi kisebb élelmiszer-szaküzletekben való élelmiszerbeszerzés aránya.

A megkérdezettek majdnem 2/3-a heti 2-3-szor föz magának vagy családjának otthon, 11,3\% hetente egyszer, míg 18,5\% minden nap. A gyakoribb főzés nagyobb arányban jellemző a nőkre és az idősebb korosztályra, míg a férfiaknál jóval gyakoribb, hogy soha nem fóznek. Minél nagyobb egy háztartás taglétszáma, és minél több gyermek van a háztartásban, annál jellemzőbb az otthoni fözés.

$\mathrm{Az}$ éttermi étkezést a ritkább gyakoriság jellemzi. A legnagyobb arányban a kitöltök 29,1\%-a jelölte, hogy évente néhányszor étkezik étteremben. $17,2 \%$ havonta, $14,8 \%$ havonta néhányszor, $18,7 \%$ uk jelezte, hogy hetente vagy hetente többször fordul ez elö. 20,3\%-uk évente, vagy soha nem megy étterembe. A férfiaknál az étterembe járás gyakoribb, mint a nőknél, hasonlóképpen a fővárosban lakókra inkább jellemző, mint a városi lakosságra, vagy a községekben lakókra. Az egyedülállók, mivel ritkábban föznek, többször étkeznek étteremben. A végzettséggel is együtt nő a gyakoriság, míg a háztartás taglétszámával és az anyagi helyzettel fordítottan arányos. Az étteremben való étkezés a szellemi foglalkozásúaknál szignifikánsan gyakoribb $(\mathrm{C}=0,150, \alpha=0,001)$.

$\mathrm{Az}$ is jól látszik, hogy az interneten való élelmiszerrendelés még viszonylag ritka. A megkérdezettek 59,9\%-a még soha nem rendelt és mindöszsze $18,9 \%$-uk tette ezt havonta vagy gyakrabban a járvány kitörését megelőzően. Inkább a férfiak próbálkoznak az interneten való élelmiszerrendeléssel, melynek aránya inkább a járvány kitörését követöen nőtt.

A fött étel rendelésének valamivel nagyobb a gyakorisága. 37,3\%-uk havonta 1-2-szer rendel, 46,2\%-uk ritkábban, míg 16,5\%-uk hetente vagy hetente többször. Ez a beszerzési mód a fiatalabb (18-45 éves) korosztályra jellemző nagyobb 
arányban. A főtt étel rendelése interneten a fiatalabb (26-35 éves) korosztályhoz köthetö.

A kis kipróbálási arány oka egyrészt a kockázat, hiszen a fizikai termék nem látható, nem próbálható ki, másrészt egy viszonylag új trendként van jelen ez a lehetőség és a szereplőktől is új típusú marketing megközelítést igényel. A kockázatot erősíti az elérhető, biztonságos fizetési módok jelenléte, alkalmazhatósága is (Szántó 2015).

\section{Döntési szempontok Decision factors}

Az élelmiszerválasztás során a döntési tényezők fontosságát 5-fokozatú skálán mértük, ahol az 5 a legfontosabb, míg az 1 a nem fontos kategóriát jelentette. Ez alapján az alábbi 2. ábrán az átlagpontszám szerinti sorrendben láthatók a döntési faktorok és az adatsorokhoz adott szórásértékek.

2. ábra: Az élelmiszerfogyasztás döntési tényezői fontosság szerint (n=928)

Figure 2. The importance of decision factors in food consumption $(n=928)$

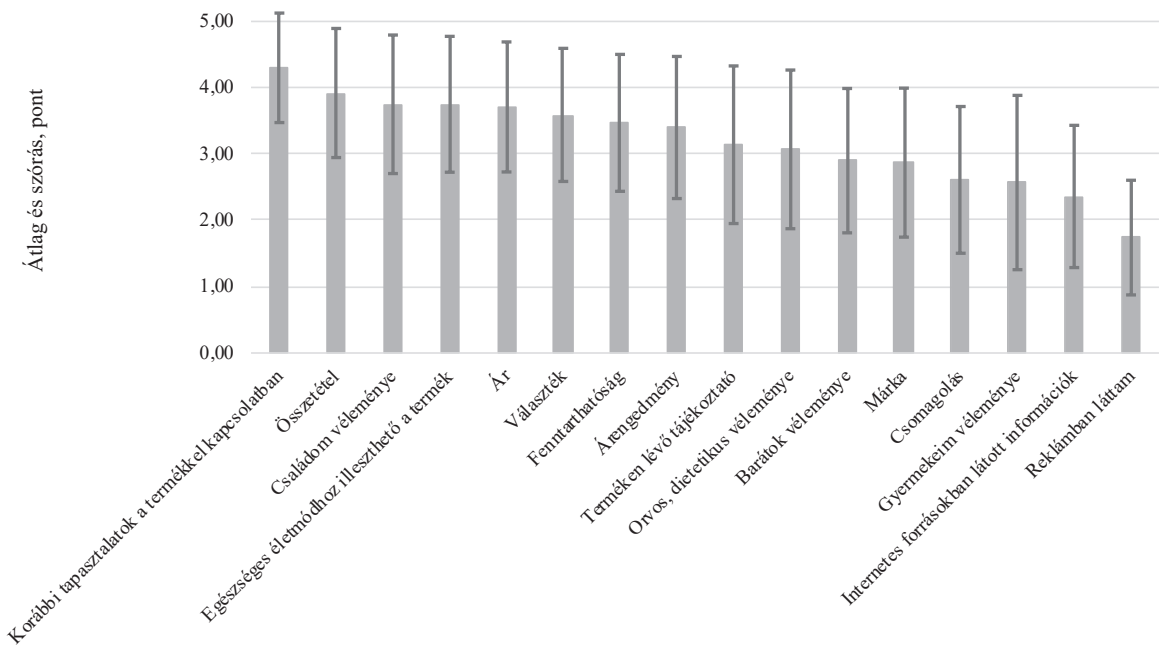

Forrás: saját szerkesztés

Meg kell jegyezni, hogy az egészségre vonatkozó információk köre korábbi felmérésünkhöz képest felértékelödött. 2012-es felmérésünkben a megkérdezettek 1/4-e jelölte az első három helyen, míg jelen kutatásunkban ez 33,4 \% és az összesített eredmény a 4 . helyre sorolta ezt a szempontot (Soós és tsai 2013).

Természetesen a döntési faktorok bemutatása mellett fontos, hogy a különböző fogyasztói szegmensek eltérő módon dönthetnek adott szituációban és a döntési szempontok is eltérő fontossági sorrendben vannak jelen, ahogy például Szakály és társai által feltárt 5 szegmens értékrendje tükrözi (Szakály és tsai 2018).

\section{Változások a járvány hatására}

\section{Changes in connection with pandemic}

A válaszadók 2,7\%-a jelezte, hogy elveszítette a munkahelyét a járvány miatt. A válaszadók 34,8\%-a home office-ban dolgozik (ebben azonban az a néhány válaszadó is benne van, aki már korábban is így dolgozott), legnagyobb arányban a fővárosban lakók. A home office a férfiak és a fiatalok között gyakoribb, míg az inaktívak nagyobb aránya nö. A munkába járás inkább a 46-55 éves korosztályban jellemzőbb. A vizsgált tényezők több tekintetben összevágnak a korábban említett Ipsos-felméréssel.

Mivel a home office-ban dolgozók aránya jelentős, így a vizsgálat kiterjedt arra is, hogy van-e eltérés a munkarend és a magatartásváltozás között. Az ANOVA-teszt és a Welch-próba eredménye azt 
mutatja, hogy a munkarend szignifikánsan befolyásolta az élelmiszerbeszerzői magatartás változását ( $F=2,459, \alpha=0,032$, ill. $W=2,896, \alpha=0,016)$. A Post Hoc Tukey-elemzés azt is megmutatta, hogy leginkább a home office-ban dolgozó és inaktív csoportok beszerzési magatartásai különböznek egymástól $(\alpha<0,05)$.

A veszélyhelyzet elrendelése a vásárlási magatartást is megváltoztatta. $54,9 \%$ változtatott a vásárlás gyakoriságán, míg 25,9\% körében a bevásárlás gyakorisága és a beszerzési forrás is változott. 5,5\% a beszerzési forrásokon változtatott, míg 13,7\% jelezte, hogy mindent úgy csinál, mint a járvány kitörését megelőzően.

Az Ernst\&Young 4859 fös mintát elemezve négy új fogyasztói szegmens kialakulását azonosított a pandémiának köszönhetően: a , Vágd visz$s z a$ " $(27,3 \%)$ csoport tagjai jelentősen visszafogják a kiadásokat minden lehetséges kategóriában. A „Légy nyugodt és folytasd” (26,2\%) kategória képviselői ugyanúgy költekeznek, mint a járvány elött tették, a „,Takarékoskodj és tartalékolj" (35,1\%) fogyasztók a legpesszimistábbak a jövőt illetően és a „Hibernálj és költs” (11,4\%) szegmens többet költ határon túli tranzakciókban (Ernst\&Young 2020).

Az élelmiszervásárlás gyakoriságát jellemzi, hogy a válaszadók több mint fele $(51,4 \%)$ hetente egyszer vásárol, $9,1 \%$ ennél ritkábban. A heti 2-3-szori beszerzés 35,8\%-ra jellemzö, míg 3,8\% naponta vásárol. A gyakoriság és az életkor között gyenge összefüggés tapasztalható. A nyugdíjasok és dolgozók közötti különbség szignifikáns $(\mathrm{F}=3,835, \alpha=0,002)$. A nehéz fizikai munkát végzők némileg gyakrabban, legnagyobb arányban hetente 2-3-szor végzik el az élelmiszer-beszerzést, míg a szellemi foglalkozásúak nagyobb arányban ritkábban, hetente 1 -szer $(C=0,110, \alpha=0,008)$.

A Statista statisztikája szerint Magyarországon a legnagyobb forgalomnövekedés (csökkenő sorrendben) az alábbi termékkörök esetén jelentkezett a járványt követően: játékok, sportfelszerelések, offline- és computertechnika és az ötödik helyen szerepel az élelmiszer (Statista 2020).

A jövőre vonatkozó, interneten való élelmiszerrendelést egy 5-fokozatú valószínüségi skálán kellett megjelölni, ahol az 5 a biztosan fog vásárolni, az 1 pedig a biztosan nem fog. Az átlageredmény 2,81 lett 1,23 szórással. A legnagyobb arányban jelölt kategória a 3-as, közepes valószínűség (33,8\%). A biztos jelölések aránya 10,7\%, míg 19,1\% biztos „nem”-et jelzett. A Statiszta 3 fokozatú skáláján a járvány hatására a megkérdezettek $23 \%$-a próbálja ki az online vásárlást, 47\%-uk biztosan nem (Statista 2020)

Vizsgáltuk, hogy a jövőbeni internetes vásárlási szándék hogyan alakul azok között, akik már szereztek be élelmiszer interneten (ez az oka a kisebb mintaelemszámnak). Az eredményeket a következő, 3. ábra mutatja.

\section{3. ábra: Az internetes élelmiszerbeszerzés választásának valószínúsége (n=270) \\ Figure 3. Probability of food purchase on internet $(n=270)$}

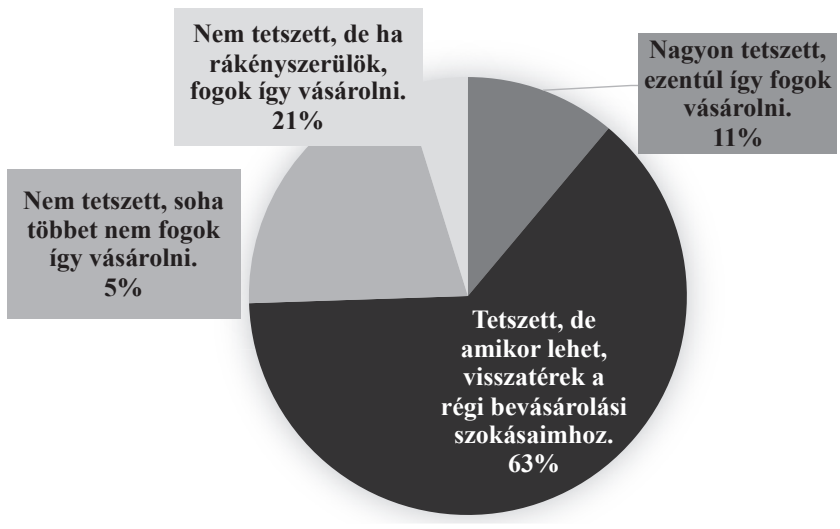

Forrás: saját szerkesztés 
Leginkább a 26-45 éves korosztály fogékony arra, hogy ezentúl interneten rendeljen élelmiszert. A végzettségcsoportok között szignifikáns eltérés van a jövőbeni internetes beszerzés tekintetében, leginkább a beszerzés későbbi valószínüsége a végzettség növekedésével nő ( $\mathrm{W}=8,567, \alpha=0,000)$. A kategória-átlagokat az alábbi, 4. ábra mutatja.

\section{4. ábra: Végzettség és az online élelmiszer-beszerzési hajlandóság összefüggése (n=928)}

Figure 4. The education level and willingness to buy food online $(n=928)$

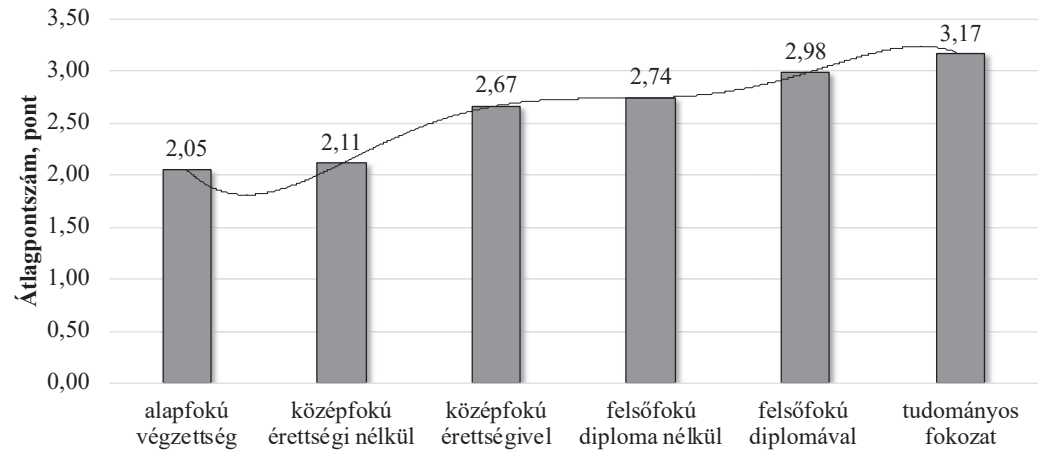

Forrás: saját szerkesztés

\section{Fizetési módok}

\section{Payment methods}

A leggyakoribb fizetési mód a bankkártyás/hitelkártyás $(58,4 \%)$ és a készpénzes $(37,9 \%)$ fizetés. Számottevő gyakorisággal még a mobilfizetés jelent meg (2,2\%), míg az egyéb módszerek (pl. átutalás, virtuális számla) kevesebb, mint 1\%-ban került említésre. Néhány említés történt a SZÉPkártyával, étkezési utalvánnyal történő fizetésre. A bankkártyás fizetés aránya a fővárosi lakosok körében a legmagasabb, ez az arány a végzettség növekedésével is nő. Az 5. ábrán látható az is, hogy ha a jövőben interneten vásárolnának élelmiszert a fogyasztók, a bankkártyás/hitelkártyás fizetések növekedése mellett a készpénzes fizetés visszaszorulása várható.

5. ábra: Fizetési módok alkalmazásának igénye $(\mathrm{n}=928)$

Figure 5. Claim to payment methods $(n=928)$

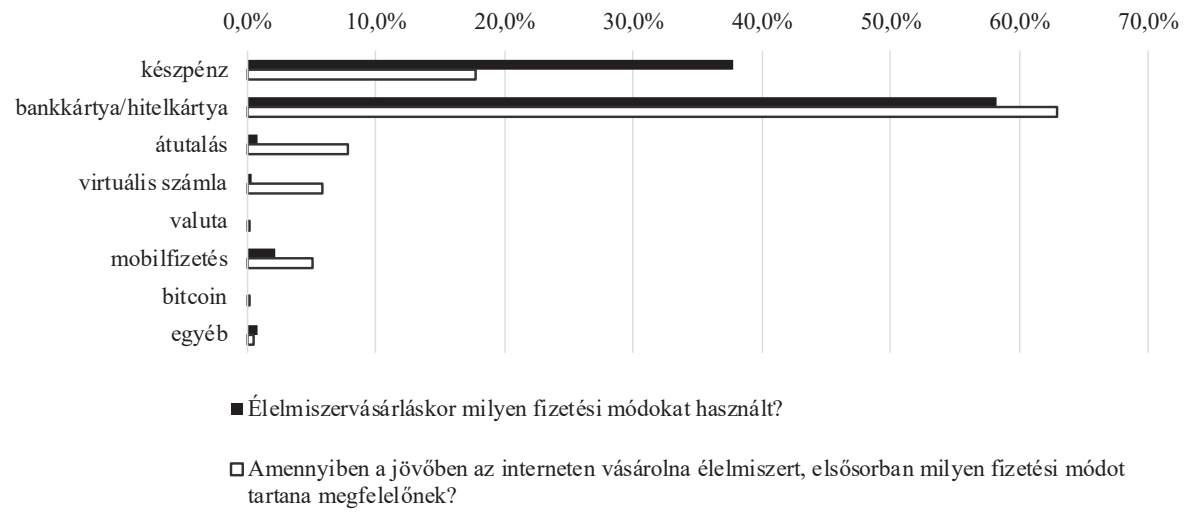

Forrás: saját szerkesztés 
Fontos, hogy az internetes beszerzés során a fogyasztó közvetlenül nem látja a terméket. Csupán egy kép és a termékleírás segíti a választásban. Emiatt felértékelődnek a korábbi tapasztalatok a döntés során. A válaszokban a döntési szempontok között ez a faktor egyértelmúen vezető szerepet tölt be. Az 5-fokozatú skálán megadható fontossági sorrendet (ahol 5 a legfontosabb és 1 a nem fontos) a 6. ábra mutatja. Az internetes vásárlási tapasztalatokkal rendelkezők válaszai alapján az oszlopok az átlagpontszámokat, a sávok pedig a szórást mutatják.

6. ábra: Az internetes élelmiszerbeszerzés döntési szempontjainak fontossága (n=278) Figure 6. The importance of decision factors in connection with the food purchase $(n=278)$

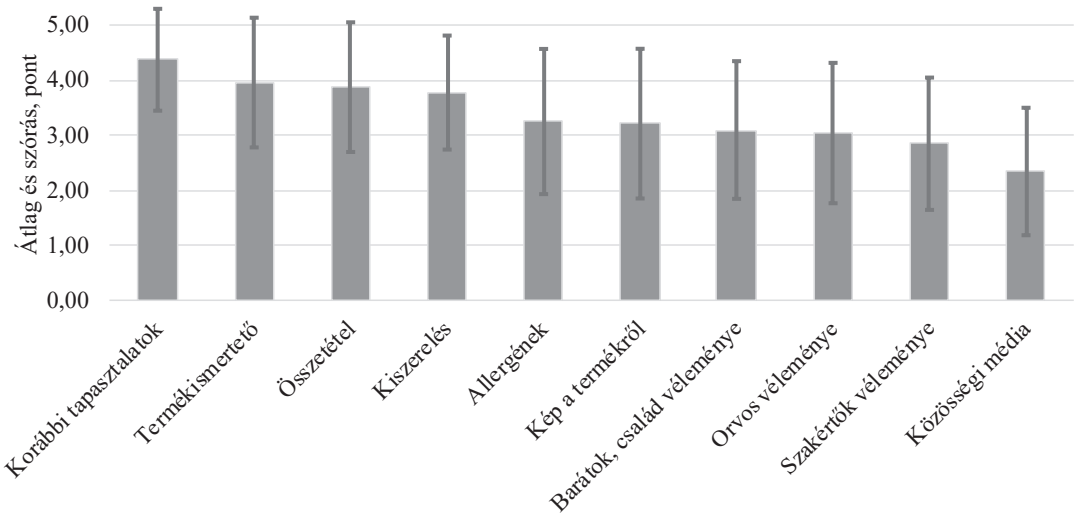

Forrás: saját szerkesztés

A kérdőív végén mértük az alapvető attitüdöt a járvánnyal kapcsolatos magatartásra és fogyasztási zokásokra vonatkozóan. Az 5-fokozatú skálán az 5 a nagyon jellemző, az 1 nem jellemző kategóriát jelentette (7. ábra).

Az otthon tartózkodás életforma lett, a válaszadók 60\%-a a legjellemzőbb kategóriaként jelölte ezt a választ. Itt a szellemi foglalkozásúak jelölték legnagyobb arányban azt, hogy alapvetően otthon tartózkodnak. Az otthon maradás a nök között valamivel nagyobb arányú, hasonlóképp a szellemi foglalkozásúaknál, valamint a felsőfokú végzettségűeknél, hiszen ez utóbbi csoportokban nyilvánvalóan könnyebben megvalósítható a home office is. Munkájuk elvesztése inkább a könnyebb fizikai munkát végzőkre volt jellemző.

$\mathrm{Az}$ egészséges táplálkozásra való odafigyelés sem javult a rendkívüli helyzetben. Az áremelkedések hatása kevésbé van komoly hatással a fogyasztók megélhetésére, a válaszadók 30\%-ára ez egyáltalán nem jellemző. A válaszadók 12,5\%-ának került veszélybe a megélhetése a járvány hatására, míg 44,9\%-ukra ez nem jellemző. 70\%-uk nem vásárol többet az interneten a veszélyhelyzet beje- lentése óta, míg 7,6\%-ukra ez jellemző.

Inkább a nőkre jellemző, hogy a veszélyhelyzet elrendelésekor készletezni kezdtek és az is, hogy a járványhelyzet miatt a megélhetésük veszélybe került. A nagyobb készletezés megvalósításában a lakásban lévő elégtelen hely a fóvárosban, illetve a megyeszékhelyen lakókat akadályozta, míg a nagybevásárlás kifizetése föként nyilvánvalóan a munkanélküliek és a rossz anyagi helyzettel rendelkezők számára okoz nehézséget, valamint a részmunkaidősök is nagyobb arányban jelezték ezt a problémát. A fogyasztási depriváltak aránya több kutatás alapján jellemzően $30 \%$ körül mozog, ezt a szegmenst mindenképpen egyedi mintázatok jellemzik (Berger 2017).

A szülők ellátása miatt a 36-55 éves korosztálynak szükséges otthonról kimozdulnia.

Látható, hogy a járvány a mindennapi életünkben, így bevásárlási szokásainkban is alapvető változásokat hozott. 
7. ábra: Járvánnyal kapcsolatos fogyasztói attitüd (n=928)

Figure 7. Consumer attitude in connection with pandemic $(\mathbf{n}=928)$

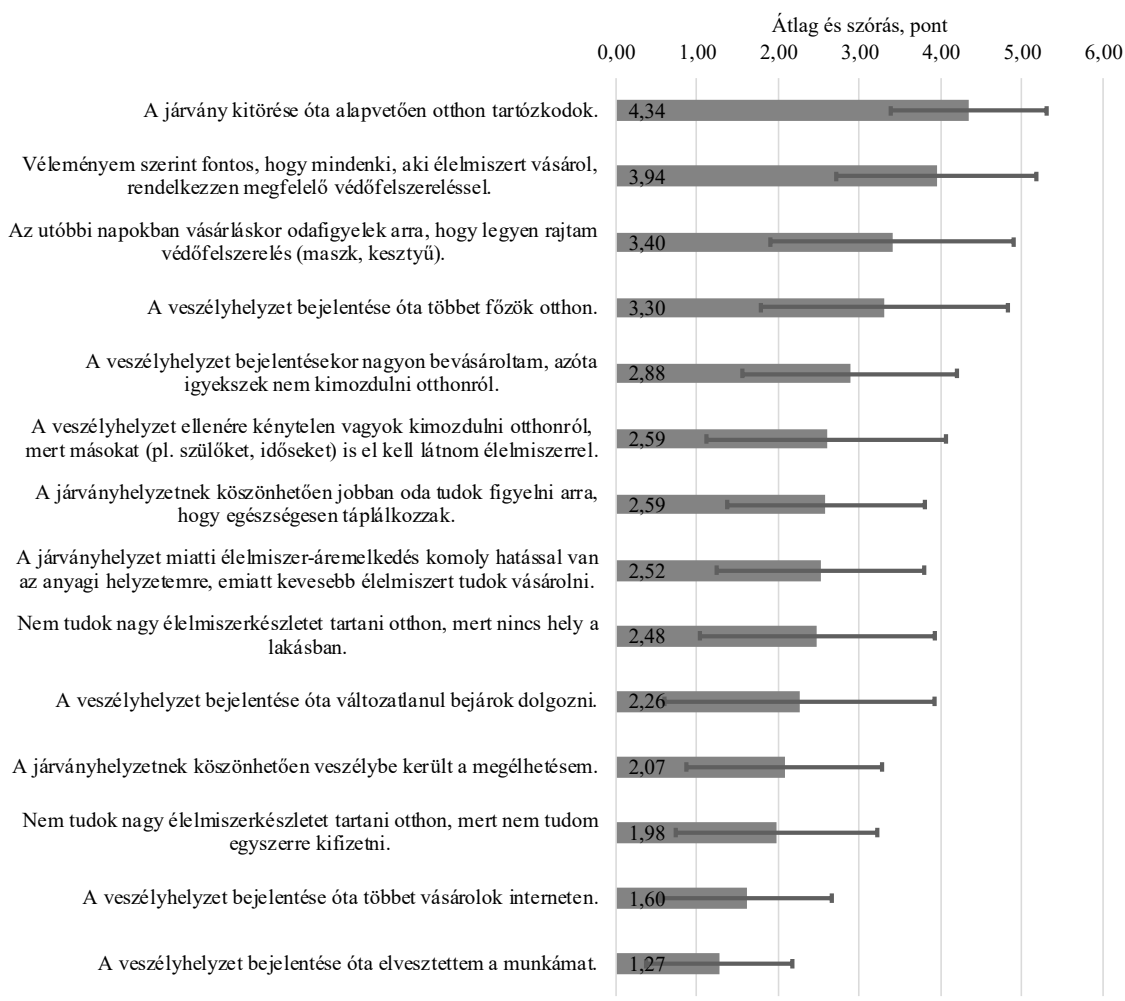

Forrás: saját szerkesztés

\section{A KUTATÁS KORLÁTAI LIMITS OF THIS RESEARCH}

A kutatás nem reprezentatív, ennek biztosítása a rendkívüli helyzetben nehéz lett volna. További korlát, hogy a kitöltés online valósult meg, így azok, akik nem rendelkeznek ilyen eszközzel, eleve kizártak a felmérésből. Az adatok a járvány kitörését követően rövid időn belül álltak rendelkezésre, így hosszú távú hatások még nem mérhetők, csak a rövid távú reakciókat tudjuk megfigyelni.

\section{KÖVETKEZTETÉSEK ÉS JAVASLATOK CONCLUSIONS AND SUGGESTION}

A fogyasztók a járványhelyzet és a korlátozások bevezetése kapcsán rendkívüli, korábban még nem tapasztalt helyzettel kerültek szembe. Gyors döntéseket kellett meghozniuk, amik többek között a fogyasztással kapcsolatos választásaikat is befolyásolták.

A beszerzést meghatározza, hogy a fogyasztók igyekeznek otthon maradni, nyilván lehetöségeikhez mérten. Ez hatással van a beszerzési források választására is. A nagyobb szuper- és hipermarketek választása csökkent és a kisebb méretü, lokális élelmiszer szaküzletek szerepe felértékelődött. Ez éppen ellentétes a korábban tapasztalt trendekkel, miszerint a hipermarketekben való bevásárlás a rohanó életmód miatt kedvező (,,mindent egy 
helyen”). Hasonlóképpen a helyben házhozszállítást vállaló kistermelők, kiskereskedők most piaci részhez juthatnak, jó minőségű szolgáltatás esetén piacaik egy részét akár hosszú távon is meg tudják tartani. Látható, hogy az élelmiszerbeszerzésben egyébként is fontos bizalom most felértékelődik, így a helyi piacok is nagyobb szerephez juthatnak, illetve fontosabbá válhat a személyes kapcsolat.

A beszerzés tekintetében eltérés van többek között a nemek tekintetében. A férfiak könnyebben rendelnek interneten élelmiszert és gyakrabban járnak étterembe, míg a nők többet főznek otthon (ahogy az a klasszikus családmodellt jellemzi). Az internetes rendelésnél meghatározó szerepe van a termékekkel kapcsolatos korábbi tapasztalatoknak, hiszen itt a terméket nem látjuk, nem tudjuk kipróbálni (mint pl. egy piacon, vagy egy hipermarketben a kóstoltatás során), hanem csak egy kép és a leírás alapján kell választanunk.

A fizikai dolgozók, illetve azok esetén, akiknél nem megoldható a home office, fontos eszköz lehet az internetes beszerzés, melyek esetén lényeges, hogy a házhoz szállítás a munkaidőn kívüli, pl. kora reggeli, vagy esti órákban is lehetséges legyen. Bár a kutatás alapján a mostani internetes vásárlási arány várhatóan némileg visszarendeződik majd a rendkívüli helyzet elmúlásával, a fizetési módok fejlesztése továbbra is fontos, lesz igény a készpénzhelyettesítő módszerek alkalmazására, de akár az érintésmentes vásárlás is tartós igény maradhat a jövőben.

A már bevált termékek választása egy rutinvásárlás során kockázatcsökkentő módszer. Itt a márkaépítés szerepe fontos és egyben segíti a választást, tehát a márkakommunikációs eszközeire érdemes hangsúlyt helyezni.

Felértékelődött az egészségre vonatkozó információ köre a korábbiakhoz képest, hiszen itt az információkeresés is több eszközt tartogat, mint hagyományos bolti szituációban. A jövőbeni marketing tevékenységekben ezt mindenképpen ki kellene használni és bővebb információkkal lehetne segíteni az egészségtudatos döntést. Például egy korábbi kutatás rámutatott, hogy a „természetes” hívószó erős hatást gyakorol a döntés során (Szücs et al. 2018).

A fogyasztók kockázatcsökkentésének fontos eszköze az élelmiszerbiztonság és az ezzel kapcsolatos tájékoztatás, amelyben az érintett hatóságok is szerephez juthatnak, illetve a hiteles tájékoztatással, garanciákkal segíthetik a döntést.

Ajövőre vonatkozóan számos kérdés felvetődik, melyek közül a legfontosabbak:

Hogyan hat a járvány a globalizációval kapcsolatos fogyasztói döntésekre?

A helyi termékek preferálása trenddé válik-e a jövöben?
A tartalékolás igénye mennyire marad fenn a veszélyhelyzet elmúlásával?

Hogyan változik az online kereskedelem volumene a jövőben és mennyire növekszik esetleg az élelmiszer-szegmensben?

\section{ÖSSZEFOGLALÁS SUMMARY}

A hirtelen kirobbant rendkívüli helyzet sokkhatást okozott számos termék piacán, az üzleti és a magánéletben, ennek következtében a fogyasztói magatartásban is. Bár jelenleg még csak szuperrövid távon tudjuk vizsgálni ezeket a változásokat, de néhány mintázat már jól kirajzolódik, melyek alapján a fogyasztók szegmentálható elsősorban nem, életkor, lakóhely, foglalkozás, vagy akár attitüd alapján.

A karantén miatt az emberek lehetőség szerint bezárkóztak otthonaikba, a kockázat most az élelmiszer-beszerzés területén is jelentkezik, ezért változtak a beszerzési források, csökkent a vásárlások gyakorisága is. Nőtt a tartalékolás igénye, amit befolyásolhat a rendelkezésre álló tárolókapacitás és a diszkrecionális jövedelem is. A bolti beszerzések esetén elv a védőfelszerelések használata, de az alkalmazás elmarad. Ennek oka lehet az, hogy a konkrét veszélyérzet még kisebb a publikált statisztikák miatt, valamint az is, hogy a hivatalos ajánlások között is megfogalmazták, hogy ez nem szükségszerü.

Az online folyamatok felé való eltolódás változtat az élelmiszerek közötti választási szempontokon is: felértékelődik a márka szerepe, mivel a korábbi tapasztalatok meghatározóak, valamint több lehetőség jut az egészséges összetevőkkel rendelkező termékek választására.

A fizetési módok az elmúlt időszakban sokat fejlődtek, így több lehetőség van készpénzhelyettesítő módszerek alkalmazására, azonban erre a gyakorlatban elsősorban a bankkártyákat, hitelkártyákat használják, ritkábban élnek az átutalás (előrefizetés) lehetőségével. A készpénzmentes (és akár érintésmentes) tranzakciók szerepe várhatóan felértékelődik, így ezen módszerek fejlesztése fontos, segíti a kereskedelmi folyamatokat (pl. virtuális számla, mobilfizetés).

Ki kell emelni, hogy a mintában egyébként is felülreprezentált szellemi foglalkozásúak számára nagyobb esély volt a home office igénybevételére, így ők azok, akik megtehetik, hogy ne mozduljanak ki otthonról, kevesebbszer vásároljanak. Ök azok, akik a járvány elött is gyakrabban jártak étterembe, most az otthoni munkavégzés megváltoztatta szokásaikat, gyakoribbá vált a hét közbeni fózés. Míg náluk a járvány kitörése számottevő életmódváltozást okozhatott, addig a fizikai munkát végzők többnyire korábbi életmódjukat folytatták, kisebb mértékü, ésszerü változtatások mellett. 


\section{HIVATKOZÁSOK REFERENCES}

Bauer, R. A. (1960), Consumer behavior as risk taking, in: Baker, M. J. (ed.), Marketing Critical perspectives on business and management, London: Routledge, 13-21

Berger V. (2017), „Szociológiai fogyasztáskutatások. Strukturális meghatározottság, szabadon lebegő életstílusok vagy valami más?", Marketing \& Menedzsment, 51(3), 1-9

Culiberg, B. and Bajde, D. (2013), "Consumer recycling: An ethical decision-making process", Journal of Consumer Behaviour, 12(6), 449-459, DOI: https://doi.org/10.1002/cb.1446

Fürediné, K. A. (2008), „A szubjektív kockázat szerepe az élelmiszerfogyasztói magatartásban a madárinfluenza járvány példáján keresztüll, Élelmiszer, táplálkozás és marketing, 5(2-3), 41-49

Knight, F. H. (1921), Risk, Uncertainty, and Profit, Indianapolis: Liberty Fund

Kulkarni, P., Prabhu, S., Kumar, D. S. and Ramraj, B. (2020), "COVID-19-Infodemic overtaking Pandemic? Time to disseminate facts over fear", Indian Journal of Community Health, 32(2), 264-269

Soós G., Biacs P., Kiss A. (2013), „Fogyasztói attitüdök a funkcionális élelmiszerfogyasztás területén", Élelmiszer, táplálkozás és marketing, 9(1), 13-21

Szakály, Z., Popp, J., Kontor, E., Kovács, S., Pető, K. and Jasák, H. (2017), "Attitudes of the Lifestyle of Health and Sustainability Segment in Hungary", Sustainability, 9(10), 1763, DOI:10.3390/su9101763

Szakály, Z., Kontor, E., Kovács, S., Popp, J., Pető, K. and Polereczki, Zs. (2018), "Adaptation of the Food Choice Questionnaire: the case of Hungary", British Food Journal, 120(7), 14741488, DOI 10.1108/BFJ-07-2017-0404
Szántó Á. (2015), "Electronic selling process", Egészségtudományi Közlemények, 4(1) 69-79

Szűcs V., Szabó E., Tarcea, M., Guerrero, L., Bánáti D. (2018), „Élelmiszeripari adalékanyagok szerepe a vásárlási döntésekben conjoint vizsgálatok alapján”, Marketing \& Menedzsment, 52(2), 69-84

Vasvári T. (2015), „Kockázat, kockázatészlelés, kockázatkezelés - szakirodalmi áttekintés", Pénzügyi Szemle, 60(1), 29-48

Ernst\&Young (2020), Four consumer behavior trends emerge during the COVID-19 pandemic, the first EY Future Consumer Index finds, https://www.ey.com/en_gl/news/2020/04/fourconsumer-behavior-trends-emerge-during-thecovid-19-pandemic-the-first-ey-future-consumer-index-finds (Utolsó letöltés: 2020. május 20.)

Ipsos (2020), Elérhető a válság hatásait fogyasztói szempontból vizsgáló kutatássorozat első heti riportja, https://www.ipsos.com/hu-hu/ elerheto-valsag-hatasait-fogyasztoi-szempontbol-vizsgalo-kutatassorozat-elso-heti-riportja (Utolsó letöltés: 2020. 04. 10.)

KSH (2020): Gyorstájékoztató Kiskereskedelem 2020. január, http://www.ksh.hu/docs/hun/xftp/ gyor/kis/kis2001.html (Utolsó letöltés: 2020. április 11.)

McKinsey (2020), Consumer sentiment evolves as the next "normal" approaches, https://www. mckinsey.com/business-functions/marketing-and-sales/our-insights/a-global-view-ofhow-consumer-behavior-is-changing-amidcovid-19 (Utolsó letöltés: 2020. május 20.)

Statista (2020), Coronavirus (COVID-19) in Hungary, https://www.statista.com/study/72886/ coronavirus-covid-19-in-hungary/ (Utolsó letöltés: 2020. május 20.) 
Soós Gabriella, adjunktus soos.gabriella@ajk.elte.hu Eötvös Loránd Tudományegyetem Állam- és Jogtudományi Kar

tanársegéd soos.gabriella@uni-eszterhazy.hu Eszterházy Károly Egyetem Gazdaság- és Társadalomtudományi Kar

\section{Changing of consumer behavior in connection with the COVID-19 pandemic in Hungary}

\section{THE AIM OF THE PAPER}

The outbreak and drastic spread of the COVID-19 pandemic has caused an economic shock that lead to a measurable change in consumer behavior. The objective of this study is to research the effect of the pandemic on consumer behavior, investigate the change in the decision factors occurring at food and grocery purchases.

\section{METHODOLOGY}

In March-April 2020 we have conducted an online questionnaire research primarily with the use of social media and mailing lists. The acquired sample is made up of 928 filled out surveys and it is not representative.

In the first segment of the questionnaire we have investigated the factors influencing choice of food. The second part focused on the change caused by the epidemic, whereas the third segment we placed the background variables. Beside descriptive statistics we applied relationship research primarily based on gender, age, profession, size of the family and income and we investigated typical behavior patterns. Following this research we have formed suggestions concerning possible marketing and commercial tools.

\section{MOST IMPORTANT RESULTS}

In the research the change in the attitude toward food purchasing in the following weeks of the announcement of the emergency was investigated. The shift in the place of the purchases is clearly measurable. Instead of bigger shopping malls, people tend to go to smaller shops and markets in greater proportion. The frequency of shopping has decreased, whereas the demand to substitute cash and use alternative paying methods has increased.

Paying with debit and credit cards is the most widespread, however prepaying, mobile paying and using virtual cards also appears. The role acquiring food from internet sources has increased, which equips the merchants with new tools, for instance for providing information regarding healthy lifestyle.

\section{RECOMMENDATIONS}

As previous experiences are relevant factors concerning the decision between groceries, building brand is exceedingly important. Furthermore, marketing communication has to target reducing risk for consumers and building greater trust between the parties.

The increased appreciation of smaller, local producers can be a long term effect, therefore the producers have to use the opportunity to build foundation for long term goals with the use of targeted communication, high quality products and services.

Food security and available information is an important tool to reduce consumer risk. With authentic provision of information and warranties the authorities play a great role in the process.

Keywords: consumer behavior, attitude, food consumption, marketing, COVID-19 